\title{
PENELUSURAN PERILAKU METAKOGNITIF MAHASISWA DALAM PEMECAHAN MASALAH MATEMATIKA
}

\author{
Dona Afriyani \\ Program Studi Tadris Matematika Jurusan Tarbiyah STAIN Batusangkar \\ Korespondensi: Jl. Jenderal Sudirman No. 137 Kuburajo Lima Kaum Batusangkar Sumatera \\ Barat, Email: donaafriyani@gmail.com
}

\begin{abstract}
This article describes self-belief and intuition, and knowledge about students' thinking process in solving problems. This research employed qualitative approach using quantitative method. Techniques of data analysis were data reduction, data display and conclusion. The finding showed that: 1) students of high group had possessed self-belief and intuition, and knowledge about students' thinking process in solving problems, but had not possessed conditional knowledge yet. 2) Students of average group had possessed good self-belief, but had not intuition and knowledge about students' thinking process in solving problems yet. 3) Students of low group had not possessed the above mentioned two metacognitive behaviors in solving problems yet.
\end{abstract}

Kata kunci: metakognitif, masalah matematika

\section{PENDAHULUAN}

Dulisan ini disarikan dari hasil penelitian yang berjudul "Penerapan Pendekatan Metakognitif untuk Menelusuri Perilaku Metakognitif Mahasiswa Tadris Matematika STAIN Batusangkar dalam Pemecahan Masalah Matematika". Tujuan penelitian adalah untuk mengetahui bagaimana keyakinan diri dan intuisi mahasiswa serta pengetahuan tentang proses berfikir mahasiswa dalam memecahkan masalah matematika. Kedua perilaku metakognitif yang ditelusuri dalam penelitian ini mengacu kepada pembagian perilaku metakognitif yang diungkapkan oleh Schoenfeld (1987: 4).

Berdasarkan hasil penelitian yang dilakukan oleh Biryukov (2004) disimpulkan bahwa komponen-komponen metakogntif (dalam hal ini sama dengan perilaku metakognitif) dapat meningkatkan kompetensi matematika mahasiswa.
Salah satu kompetensi yang ingin dicapai melalui pembelajaran matematika adalah kecakapan peserta didik dalam memecahkan masalah. National Council of Teachers of Mathematics (NCTM, 1999: 16), menyatakan bahwa pemecahan masalah matematika dalam pengertian yang lebih luas hampir sama dengan "bermatematika" dan melalui pemecahan masalah, peserta didik dapat membangun pengetahuan matematika baru. Langkahlangkah pemecahan masalah menurut Polya, yaitu: memahami masalah, merencanakan strategi penyelesaian masalah, melaksanakan strategi yang sudah direncanakan, dan mengevaluasi penyelesaian masalah yang sudah dibuat.

Proses penelusuran perilaku metakognitif mahasiswa yang terlibat dalam setiap langkah penyelesaian masalah di atas diharapkan dapat mengenali kesulitan-kesulitan yang dihadapi mahasiswa dalam memecahkan masalah matematika. Rumusan masalah penelitian yang 
dijawab melalui penelitian ini adalah: 1 . Bagaimanakah keyakinan diri dan intuisi mahasiswa dalam memecahkan masalah matematika?, 2. Bagaimanakah pengetahuan tentang proses berfikir mahasiswa dalam memecahkan masalah matematika? Untuk mendapatkan hasil yang lebih spesifik, mahasiswa dikelompokkan berdasarkan perolehan belajar (gain ternormalisasi) yang dicapainya. Perhitungan gain ternormalisasi $(g)$ merujuk kepada kriteria yang diungkapkan oleh Meltzer (2002: 8), yaitu perolehan belajar rendah jika $\mathrm{g}<0,3$; perolehan belajar sedang jika $0,3 \leq \mathrm{g}<0,7$ dan perolehan belajar tinggi jika $\mathrm{g} \geq 0,7$.

Penelitian ini dilatarbelakangi oleh kurang berhasilnya mahasiswa dalam memecahkan masalah matematika, khususnya masalah non-routine dan openended. Indikator ketidakberhasilan ini dapat dilihat dari berbagai hal, diantaranya hasil belajar matematika masih rendah, dosen mengalami kesulitan dalam menerapkan strategi pembelajaran yang mengarah kepada upaya peningkatan kemampuan pemecahan masalah, penyadaran proses berfikir mahasiswa dan penilaian selama ini lebih kepada hasil kognitif saja tanpa memperhatikan perkembangan proses kognitif mahasiswa.

Kekurangmampuan dosen dalam mengelola dan mengembangkan proses berfikir mahasiswa berwujud pada pelaksanaan pembelajaran matematika yang mekanistik. Hampir di setiap pembelajaran matematika, dosen memberikan sejumlah rumus dan menjelaskan sebuah contoh persoalan sederhana dari penggunaan rumus tersebut. Mahasiswa diberitahu berbagai prosedur rutin untuk menyelesaikan persoalan matematika, tanpa diikutsertakan dalam memikirkan logical basic dari setiap langkah yang harus mereka kerjakan. Pembelajaran yang seperti ini berakibat pada kurangnya senses of mathemathic. Akibatnya, gaya belajar matematika lebih kepada menghafal rumus dan cara penyelesaian soal yang sudah pernah dibahas, sehingga peserta didik tidak mampu mengkoneksikan materi yang satu dengan yang lain dan menyelesaikan persoalan yang lebih bervariasi dan kompleks.

Melihat substansi dari permasalahan di atas, perlu dilakukan beberapa upaya agar mahasiswa sukses dalam memecahkan masalah matematika. Mereka perlu dilibatkan dalam menemukan atau membangun konsep dan aktif berfikir dalam menyelesaikan masalah-masalah matematika. Kemampuan kognitif mahasiswa perlu disadarkan sehingga mereka dapat merangkai ide yang dimilikinya untuk menemukan berbagai alternatif solusi yang bernilai benar. Dalam proses perkuliahan, dosen lebih menjembati pencapaian pemahaman konsep atau masalah dengan senantiasa memberikan pertanyaan yang bersifat metakognitif. Rangsangan seperti ini dapat melatih dan meningkatkan daya fikir mahasiswa, karena dalam setiap langkah pemecahan masalah yang dikerjakan, mahasiswa senantiasa memunculkan pertanyaan: "Apa yang saya kerjakan?", "Mengapa saya mengerjakan ini?", "Hal apa yang bisa membantu saya dalam menyelesaikan masalah ini?". "Apakah saya tidak melakukan kesalahan", "Kenapa hasilnya seperti ini?", dan lain-lain. Kemampuan mahasiswa bertanya pada diri sendiri dan kemampuan menjawab pertanyaan-pertanyaan tersebut menunjukkan bahwa mahasiswa memiliki perilaku-perilaku metakognitif dalam memecahkan masalah (Taccasu Project, 2008: 10).

Berdasarkan karakteristik bahwa proses yang dilakukan berupa tindakan untuk menyadarkan kemampuan kognitif mahasiswa, maka proses penyadaran kemampuan kognitif mahasiswa ini merupakan upaya secara metakognitif, mahasiswa dipandu untuk dapat menyadari apa yang mereka ketahui dan apa yang mereka tidak ketahui serta bagaimana 
mereka memikirkan hal tersebut agar masalah dapat diselesaikan. Dengan demikian, mahasiswa akan lebih mudah dalam memecahkan permasalahan matematika. Untuk itu, dosen perlu mengenali perilaku metakognitif mahasiswanya dalam memecahkan masalah matematika.

\section{KAJIAN TEORITIS}

Metakognitif merupakan kata sifat dari metakognisi. Metakognisi berasal dari kata "metacognition" dengan prefik "meta" dan kata "kognisi". Meta berasal dari bahasa Yunani yang berarti "setelah", "melebihi", atau "di atas". Secara umum kognisi diartikan sebagai apa yang diketahui serta difikirkan oleh seseorang. Gambaran klasik mengenai kognisi meliputi "Higher Mental Processes" seperti pengetahuan, kesadaran, inteligensi, pikiran, imajinasi, daya cipta, perencanaan, penalaran, penyimpulan, pemecahan masalah, pembuatan konsep, pembuatan klasifikasi-klasifikasi dan kaitan-kaitan, pembuatan simbol-simbol dan mungkin juga fantasi serta mimpi. Metakognitif mengacu kepada kesadaran mahasiswa terhadap kemampuan yang dimilikinya serta kemampuan untuk memahami, mengontrol dan memanipulasi proses-proses kognitif yang mereka miliki.

Metakognitif siswa melibatkan pengetahuan dan kesadaran siswa tentang aktivitas kognitifnya sendiri atau segala sesuatu yang berhubungan dengan aktivitas kognitifnya. Menurut OLRC News yang dikutip oleh Kuntjojo (2009: 1), kedua pengetahuan mengenai proses berfikir dan pengaturan diri merupakan komponen-komponen dari metakognitif, yang masing-masingnya memiliki subsub komponen sebagai berikut;

a. Pengetahuan tentang kognisi

1) Pengetahuan deklaratif, yaitu pengetahuan tentang diri sendiri sebagai pelajar, serta strategi, ke- terampilan, dan sumber-sumber belajar yang dibutuhkan untuk keperluan belajar.

2) Pengetahuan prosedural, yaitu pengetahuan tentang bagaimana menggunakan apa yang telah diketahui dalam pengetahuan deklaratif tersebut dalam aktivitas belajar.

3) Pengetahuan kondisional, yaitu pengetahuan tentang kapan sebaiknya menggunakan suatu prosedur, keterampilan, atau strategi dan bilamana hal-hal tersebut tidak digunakan, mengapa suatu prosedur bisa berlangsung dan dalam kondisi yang bagaimana berlangsungnya, dan mengapa suatu prosedur lebih baik daripada prosedur yang lain.

b. Regulasi tentang kognisi

1) Planning, yaitu kemampuan merencanakan aktivitas belajarnya.

2) Information management strategies, yaitu kemampuan mengelola informasi berkenaan dengan proses belajar yang dilakukan.

3) Debugging strategies, yaitu kemampuan membetulkan tindakantindakan yang salah dalam belajar.

4) Evaluation, yaitu kemampuan mengevaluasi efektivitas strategi belajarnya, apakah ia akan mengubah strateginya, menyerah pada keadaan, atau mengakhiri kegiatan tersebut.

Secara khusus, Schoenfeld (1987: 4) menandai tiga kategori perilaku metakognitif dalam pemecahan masalah, yaitu: keyakinan diri dan intuisi, pengetahuan tentang proses berfikir, dan kesadaran diri atau pengaturan diri. Keyakinan diri dan intuisi menyangkut ideide matematika apa yang disiapkan untuk menyelesaikan masalah matematika dan bagaimana ide-ide tersebut dapat membentuk jalan/cara untuk menyelesaikan masalah matematika. Kelihatannya, Schoenfeld memberikan keyakinan diri dan intuisi ini sebagai 
proses metakognitif dimana sebelum seseorang dapat mengerjakan, ia memiliki keyakinan bahwa masalah dapat diselesaikan, ia juga memiliki intuisi bahwa masalah yang timbul dapat diselesaikan dengan ide-ide dan proses tertentu. Dengan memiliki kategori keyakinan diri dan intuisi ini berarti mahasiswa berusaha untuk memiliki kepercayaan diri bahwa ia dapat menyelesaikan permasalahan itu.

Pengetahuan mengenai proses berfikir seseorang ini berkaitan dengan seberapa akurat seseorang dapat menggambarkan mengenai pemikirannya. Pada bagian ini Schoenfeld lebih menekankan pada proses pengorganisasian atau pengelolaan pengetahuan yang berhubungan dengan proses berfikir dalam memecahkan masalah. Kesadaran diri atau pengaturan diri, ini berkaitan dengan keakuratan seseorang dalam menjaga dan mengatur apa yang harus dilakukannya ketika menyelesaikan masalah. Schoenfeld (1992: 60) menyarankan bahwa kesadaran diri atau pengaturan diri dapat menggunakan pendekatan pengelolaan yang meliputi beberapa aspek, yaitu; mengakses pemahaman terhadap masalah secara keseluruhan, merencanakan strategi penyelesaian, memonitor dan mengontrol cara-cara penyelesaian berjalan, dan mengalokasikan hasil, memutuskan apa yang harus dilakukan, dan berapa lama masalah tersebut diselesaikan. Bagaimana keyakinan diri dan intuisi serta pengetahuan tentang proses berfikir mahasiswa di setiap langkah pemecahan masalah yang diungkapkan Polya merupakan hasil dari penelitian ini.

\section{METODOLOGI PENELITIAN}

Metode penelitian yang digunakan adalah metode penelitian kualitatif dengan pendekatan deskriptif. Subjek penelitian yang digunakan adalah mahasiswa Tadris Matematika yang meng- ambil matakuliah Statistika Matematika yang berjumlah 33 orang. Jenis data yang dikumpulkan berupa data tes hasil belajar, data hasil observasi dan wawancara berupa perilaku metakognitif mahasiswa dalam memecahkan masalah matematika. Teknik pengumpulan data yang digunakan adalah observasi, tes hasil belajar, dan wawancara. Analisis data dimulai dengan melakukan reduksi data, penyajikan data, dan penarikan kesimpulan.

\section{HASIL PENELITIAN}

Seperti dijelaskan sebelumnya, mahasiswa dikelompokkan berdasarkan gain ternormalisasi yang dicapainya, yaitu mahasiswa dengan gain keterampilan pemecahan masalah tinggi, sedang, dan rendah. Jumlah mahasiswa menurut klasifikasi perolehan hasil belajar dapat dilihat pada Tabel 1 berikut ini.

Tabel 1: Jumlah Mahasiswa Berdasarkan Klasifikasi Skor Gain

Ternormalisasi

\begin{tabular}{|c|c|c|c|c|}
\hline Kategori & Kriteria & $\begin{array}{l}\text { Nilai } \\
\text { Huruf }\end{array}$ & $\begin{array}{c}\text { Jumlah } \\
\text { Mahasiswa }\end{array}$ & Total \\
\hline \multirow{2}{*}{ Rendah } & \multirow{2}{*}{$\mathrm{g}<0,3$} & $\mathrm{E}$ & 0 & \multirow{2}{*}{1} \\
\hline & & $\mathrm{D}$ & 1 & \\
\hline \multirow{3}{*}{ Sedang } & \multirow{3}{*}{$\begin{array}{c}0,3 \leq \mathrm{g} \\
<0,7\end{array}$} & $\mathrm{D}$ & 3 & \multirow{3}{*}{16} \\
\hline & & $\mathrm{C}$ & 3 & \\
\hline & & B & 10 & \\
\hline \multirow[b]{2}{*}{ Tinggi } & \multirow{2}{*}{$\mathrm{g} \geq 0,7$} & B & 4 & \multirow[b]{2}{*}{16} \\
\hline & & $\mathrm{A}$ & 12 & \\
\hline
\end{tabular}

Perilaku metakognitif mahasiswa ketiga kelompok gain ternormalisasi di setiap langkah pemecahan masalah yang diungkapkan oleh Polya, adalah sebagai berikut;

\section{Keyakinan Diri dan Intuisi}

\section{Mahasiswa Kelompok Tinggi}

Berdasarkan hasil wawancara diperoleh informasi bahwa keseluruhan 
mahasiswa kelompok tinggi telah memiliki keyakinan bahwa mereka mampu menyelesaikan persoalan-persoalan yang diberikan. Keyakinan yang muncul disebabkan karena mereka telah memahami konsep yang mendasari penyelesaian persoalan yang akan dipecahkan. Mereka juga menyadari bahwa mereka memiliki sebuah atau sejumlah ide dan proses tertentu untuk menyelesaikan persoalan yang diberikan. Hal ini didukung oleh hasil belajar yang dicapai oleh mahasiswa kelompok tinggi, yaitu tergolong kategori sangat tinggi dan tinggi. Mereka dapat memutuskan ide yang tepat untuk memecahkan persoalan yang diberikan. Hal ini dapat dilihat pada lembar jawaban masing-masing mahasiswa kelompok tinggi.

Hasil yang diperoleh oleh mahasiswa kelompok tinggi tersebut sangat didukung oleh keyakinan diri dan intuisi yang dimilikinya dalam menyelesaikan masalah. Keyakinan diri dan intuisi yang mereka miliki tidak lepas dari pengaruh penanaman konsep yang berlangsung dengan menjawab pertanyaaan-pertanyaan yang mendasari konsep, sehingga mereka memiliki kecakapan mengerjakan matematika dan memahami sifatsifat matematika. Hal ini berpengaruh terhadap bagaimana mereka menyelesaikan soal (Van De Walle, 2008: 60). Jadi keyakinan diri dan intuisi ini merupakan perilaku metakognitif yang sangat diperlukan untuk memulai memecahkan masalah dan mahasiswa kelompok tinggi telah memiliki perilaku tersebut.

\section{Mahasiswa Kelompok Sedang}

Berdasarkan penelusuran melalui wawancara dengan semua mahasiswa kelompok sedang ditemukan bahwa mereka semuanya merasa yakin bisa menyelesaikan persoalan-persoalan yang diberikan, karena mereka telah memahami konsep Kombinatorik dan Peluang. Namun pada hasil kerja mereka ditemukan bahwa mereka masih mem- buat kekeliruan dalam memutuskan ide penyelesaian masalah. Kebanyakan mahasiswa kelompok sedang yang mendapatkan nilai B belum mampu menggunakan ide yang tepat untuk soal nomor 2 dan 4, sedangkan yang mendapatkan nilai $\mathrm{C}$ dan $\mathrm{D}$ belum mampu menggunakan ide yang tepat untuk soal nomor 1, 2, dan 4. Jadi mahasiswa kelompok sedang sudah mempunyai rasa percaya diri bahwa mereka mempunyai ide untuk menyelesaikan masalah, tetapi ide yang digunakan masih belum tepat. Hal ini diduga karena pemahaman konsep yang dimiliki kelompok ini kurang maksimal. Padahal keyakinan diri dan intuisi harus dimiliki oleh seseorang agar sukses dalam menyelesaikan masalah (Schoenfeld, 1992: 69).

\section{Mahasiswa Kelompok Rendah}

Pada saat wawancara, mahasiswa kelompok rendah mengakui bahwa setelah mendapatkan pembelajaran tentang konsep Kombinatorik dan Peluang, dirinya merasa yakin bisa menyelesaikan persoalan Kombinatorik dan Peluang. Artinya, ia memiliki ide tertentu untuk menyelesaikan persoalan tersebut. Berikut ini disajikan petikan wawancara dengan mahasiswa tersebut.

$\mathrm{P}$ :Apakah Anda memiliki ide untuk menyelesaikan persoalan 2 ?

$\mathrm{M}$ : ya permutasi dengan $\mathrm{n}$ objek yang berbeda

P : Apakah Anda yakin bisa menyelesaikan persoalan Kombinatorik dan Peluang?

M : untuk soal nomor 2 saya yakin, tapi untuk soal yang berbeda dengan soal yang pernah saya kerjakan saya merasa tidak mampu menyelesaikannya

Menurut petikan wawancara di atas tampak bahwa mahasiswa kelompok rendah belum memiliki keyakinan diri dan intuisi untuk memulai menyelesaikan masalah. Mahasiswa tersebut mengungkapkan bahwa soal nomor 2 diselesaikan dengan menggunakan rumus 
permutasi dengan $n$ objek yang berbeda. Pada saat ujian pun ia membuat demikian. Selain itu, ia mengungkapkan bahwa ia sering kewalahan menyelesaikan soal-soal yang tidak mirip dengan soal yang pernah ia kerjakan sebelumnya pada latihan.

\section{Pengetahuan tentang Proses Berfikir}

Pengetahuan mahasiswa kelompok tinggi tentang proses berfikir dalam memecahkan masalah matematika, meliputi: pengetahuan tentang proses berfikir dalam memahami masalah, menjalankan strategi penyelesaian masalah, dan pengetahuan kondisional.

\section{Pengetahuan Tentang Proses Berfikir Dalam Memahami Masalah.}

\section{Mahasiswa Kelompok Tinggi}

Mahasiswa kelompok tinggi sudah memiliki pengetahuan tentang perlunya menyajikan kembali masalah ke dalam bentuk yang lebih sederhana dan mudah dimengerti. Dilihat dari hasil kerja mahasiswa kelompok tinggi, mereka sudah mengelompokkan informasi pada soal ke dalam bagian yang diketahui dan ditanya, tetapi sebagian besar dari penyajian masalah yang dibuat belum menggunakan bahasa matematika yang lebih operasional. Artinya, mereka lebih cenderung memenggal kalimat-kalimat yang terdapat pada soal atau tidak menyajikan informasi menggunakan lambang-lambang matematika (lebih operasional).

Berdasarkan penelusuran lanjutan melalui wawancara dengan seluruh mahasiswa kelompok tinggi, diperoleh informasi bahwa mereka terbiasa menyajikan masalah ke dalam bagian yang diketahui dan ditanya. Hal ini mereka lakukan dengan tujuan untuk memudahkan mereka dalam menemukan ide penyelesaian masalah. Artinya, mahasiswa kelompok tinggi sudah memiliki pengetahuan bahwa menyajikan masalah merupakan hal penting untuk dilakukan agar mudah memahami masalah. Dengan menentukan secara cermat apa yang diketahui dan apa yang ditanyakan menjadi petunjuk arah penyelesaian masalah.

Mahasiswa kelompok tinggi sudah dapat mengelola atau mengorganisasikan pengetahuan yang berhubungan dengan proses berfikir dalam memahami masalah. Artinya, mereka sudah memiliki pengetahuan tentang proses berfikir dalam memahami masalah (Schoenfeld, 1992: 53). Namun, pengetahuan ini tidak didukung oleh kemampuan dalam merepresentasikan informasi dalam soal dengan menggunakan bahasa matematika. Peneliti menduga bahwa mereka belum memiliki pengetahuan prosedural dalam menyelesaikan masalah matematika. Selain itu mereka juga belum mampu menggambarkan secara akurat mengenai pemahamannya terhadap masalah. Hal ini berdasarkan studi hasil kerja mahasiswa, yaitu masih ditemukan informasi penting yang belum disajikan.

\section{Mahasiswa kelompok Sedang}

Dari hasil kerja mahasiswa pada saat tes akhir ditemukan bahwa 14 orang dari 16 orang mahasiswa kelompok sedang sudah menyajikan masalah ke dalam bentuk yang lebih sederhana. Sisanya langsung membuat penyelesaian masalah tanpa menyajikan masalah terlebih dahulu. Penyajian masalah yang dibuat mahasiswa kelompok sedang adalah dengan mengelompokkan informasi ke dalam bagian yang diketahui dan ditanya. Namun bahasa yang digunakan belum operasional dan masih terdapat informasi penting yang belum diungkapkan pada penyajian masalah.

Informasi lebih lanjut yang diperoleh melalui wawancara yaitu, mahasiswa kelompok sedang yang sudah terbiasa menyajikan masalah ke dalam bentuk yang lebih sederhana dan mudah dimengerti baik pada saat ujian maupun saat mengerjakan latihan di rumah sebanyak 11 orang. Dua orang mahasiswa, yaitu mahasiswa S4 dan S16 
mengungkapkan bahwa mereka hanya membuat penyajian masalah pada saat ujian atau tugas yang akan dikumpulkan saja, sedangkan untuk latihan di rumah mereka jarang membuat penyajian masalah.

Tidak semua mahasiswa kelompok sedang memiliki kebiasaan menyajikan masalah yang telah mereka pahami. Sebagian dari mereka lebih suka langsung menjawab persoalan tanpa merumuskan permasalahan terlebih dahulu. Padahal terdapat empat proses metakognitif dalam menyelesaikan masalah, yaitu mengidentifikasi masalah, menyajikan masalah, merencanakan aksi, evaluasi penyelesaian masalah (Davidson, Deuser, dan Sternberg dalam Yimer, 1997: 2). Selain itu, mahasiswa kelompok sedang belum mengetahui bahwa orang yang lancar dalam memecahkan masalah telah mengembangkan keterampilan dalam mengungkapkan masalah (Albrecht, 2005: 165).

Mahasiswa kelompok sedang yang tidak biasa menyajikan masalah mengungkapkan bahwa sebenarnya dirinya memahami masalah, tetapi tidak biasa menyajikannya. Dari ungkapan tersebut dapat disimpulkan bahwa mereka tidak memiliki pengetahuan bahwa untuk memahami masalah secara komprehensif masalah tersebut, perlu dituliskan kembali. Padahal kegiatan menulis merupakan proses reflektif (Van De Wille, 2008: 54). Bentuk penyajian masalah yang dibuat oleh sebagian mahasiswa kelompok sedang, yaitu memisahkan informasi ke dalam bagian yang diketahui dan ditanya, namun bahasa yang digunakan belum operasional.

\section{Mahasiswa Kelompok Rendah}

Pada saat wawancara, mahasiswa kelompok rendah mengungkapkan bahwa dirinya telah biasa menyajikan masalah dan penyelesaian masalah secara sistematis. Masalah disajikan dengan menggunakan lambang-lambang, karena dengan membuatkan lambang-lambang ia akan mudah mengingat rumus yang tepat digunakan untuk menyelesaikan masalah ini. Dilihat dari hasil kerja, hampir semua masalah disajikan dalam bentuk lambang-lambang, tetapi tidak dilengkapi dengan keterangan tentang lambang tersebut. Selain itu informasi yang disajikan hanya yang bersifat angka saja, akibatnya banyak informasi penting yang tidak disajikan.

\section{Pengetahuan Tentang Proses Berfikir Dalam Menjalankan Strategi Penye- lesaian Masalah}

\section{Mahasiswa Kelompok Tinggi}

Berdasarkan hasil kerja mahasiswa, penyajian penyelesaian masalah yang dibuat oleh mahasiswa kelompok tinggi dapat dibedakan menjadi dua, yaitu; Pertama, sebagian besar mahasiswa kelompok tinggi sudah akurat dalam menguraikan langkah demi langkah penyelesaian masalah yang dibuat dan sudah dilengkapi dengan keterangan-keterangan yang berfungsi sebagai alasan penggunaan rumus. Kedua, terdapat 5 orang diantara mahasiswa kelompok tinggi yang belum memberikan alasanalasan dari setiap langkah penyelesaian masalah dan belum membuat kesimpulan dari penyelesaian masalah yang dibuat.

Dari wawancara yang dilakukan dengan seluruh mahasiswa kelompok tinggi diperoleh informasi bahwa setiap memecahkan masalah, mereka lebih cenderung menyajikan penyelesaian masalah secara sistematis. Walaupun demikian, pada lembar jawaban tes akhir mahasiswa masih ditemukan kekurangan dalam memberikan alasan yang logis dari setiap langkah penyelesaian masalah. Ternyata saat diwawancarai, mereka mampu memberikan alasan-alasan yang logis dari jawaban yang mereka buat.

Hal ini diperkuat oleh hasil wawancara yang juga memperlihatkan bah- 
wa mereka lebih cenderung menyajikan penyelesaian masalah secara sistematis. Mereka menyadari bahwa proses berfikir selama menyelesaikan masalah menjadi lancar jika penyelesaian masalah diuraikan secara lengkap. Selain itu, mereka juga menyadari bahwa penyajian penyelesaian masalah seperti itu akan memudahkan mereka dalam mengidentifikasi kekeliruan yang diperbuat selama menyelesaikan masalah. Artinya, mereka sudah memiliki perilaku atau kebiasaan menyajikan prosedur penyelesaian masalah secara rinci dan dilengkapi alasanalasan logis sebagai dasar berfikir dari setiap langkah yang dibuat.

Di samping itu, mereka juga sudah akurat dalam menggambarkan proses berfikir dalam menyelesaikan masalah. Hal ini berarti mahasiswa kelompok tinggi sudah memiliki pengetahuan tentang proses berfikir dalam menyelesaikan masalah, khususnya selama menjalankan strategi penyelesaian masalah. Mereka juga sudah memiliki pengetahuan prosedural yaitu pengetahuan tentang langkah demi langkah dalam menyelesaikan masalah.

\section{Mahasiswa kelompok Sedang}

Hasil studi tentang hasil kerja mahasiswa menunjukkan bahwa hanya sebagian kecil (3 dari 16 orang mahasiswa) mahasiswa kelompok sedang yang mampu menyajikan penyelesaian masalah secara lengkap dan sistematis. Hal ini diperkuat oleh hasil wawancara yang juga memperlihatkaan bahwa mereka lebih cenderung menyajikan penyelesaian masalah secara sistematis. Mereka menyadari bahwa proses berfikir selama menyelesaikan masalah menjadi lancar jika penyelesaian masalah diuraikan secara lengkap.

Selain itu mahasiswa juga menyadari bahwa penyajian penyelesaian masalah seperti itu akan memudahkan mereka dalam mengidentifikasi kekeliruan yang diperbuat selama menyelesaikan masalah. Artinya, tiga orang mahasiswa kelompok sedang tersebut sudah memiliki perilaku atau kebiasaan menyajikan prosedur penyelesaian masalah secara rinci dan dilengkapi alasan-alasan logis sebagai dasar berfikir dari setiap langkah yang dibuat. Meskipun prosedur penyelesaian masalah yang disajikan oleh ketiga orang mahasiswa tersebut tergolong sistematis dan lengkap, namun hasil belajar yang dicapai hanya masuk kategori tinggi (B). Hal ini disebabkan oleh penggunaan ide yang tidak tepat pada pemecahan masalah beberapa buah soal.

Bentuk kedua dari gaya penyajian masalah yang dibuat oleh delapan orang mahasiswa kelompok sedang, yaitu mereka sudah memberikan alasan-alasan logis yang mendasari langkah demi langkah penyelesaian masalah, namun masih kurang dalam menginterpretasikan lambang-lambang matematika yang digunakan. Dari hasil penelitian dapat disimpulkan bahwa delapan orang mahasiswa ini sudah memiliki pengetahuan prosedural. Salah satu bentuk pengetahuan prosedural dalam menyelesaikan masalah "Kombinatorik" adalah kemampuan dalam menguraikan bentuk faktorial.

Kekurangan dari delapan orang mahasiswa tersebut, yaitu kurang akurat dalam menggambarkan proses berfikirnya. Mereka tidak mampu memberikan interpretasi dari simbol matematika yang digunakan. Artinya, mereka belum akurat dalam menggambarkan proses berfikirnya ketika memecahkan masalah. Dengan kata lain, mahasiswa kelompok sedang belum memiliki pengetahuan tentang proses berfikirnya yang cukup selama memecahkan masalah (Schoenfeld, 1989: 3). Hal yang sama juga terjadi pada lima orang mahasiswa yang penyajian penyelesaian masalahnya tidak sistematis. Penyajian prosedur penyelesaian masalah yang tidak akurat menyebabkan proses monitoring terhadap tindakan yang salah kurang terlaksana. 


\section{Mahasiswa Kelompok Rendah}

Pada saat wawancara, mahasiswa kelompok rendah mengungkapkan bahwa dirinya terbiasa menyajikan prosedur penyelesaian masalah secara sistematis. Hal ini ia lakukan supaya terhindar dari kesalahan. Namun yang dimaksudkan sistematis oleh mahasiswa kelompok rendah ini tidak sistematis dalam arti yang sebenarnya. Artinya, penyelesaian masalah yang dibuat sudah rapi, tetapi prosedur yang ia lalui tidak tepat. Berdasarkan studi terhadap hasil kerja mahasiswa kelompok rendah, dapat disimpulkan bahwa ia belum akurat dalam menggambarkan proses berfikirnya. Ia hanya memfokuskan pada penyajian penyelesaian masalah dalam bentuk lambang-lambang matematika saja, tanpa membubuhi keterangan dari lambang tersebut dan kenapa formula matematika tersebut digunakan. Dengan kata lain mahasiswa kelompok rendah belum memiliki pengetahuan tentang proses berfikir dalam menjalankan strategi penyelesaian masalah dan tidak akurat dalam menggambarkan proses berfikir dalam menyelesaikan masalah.

\section{Pengetahuan Kondisional}

\section{Mahasiswa Kelompok Tinggi}

Berdasarkan hasil wawancara dengan seluruh mahasiswa kelompok tinggi ditemukan 13 orang dari 16 orang mahasiswa kelompok tinggi belum mencoba menemukan alternatif solusi lain yang bernilai benar dari sebuah persoalan. Sewaktu wawancara, pada umumnya mahasiswa kelompok tinggi mengungkapkan bahwa mereka tidak mau mencoba memecahkan masalah dengan berbagai alternatif solusi yang bernilai benar karena kekhawatiran timbulnya keraguan terhadap konsep yang sudah dipelajari. Artinya mahasiswa kelompok tinggi pada umumnya belum memiliki pengetahuan kondisional dalam memecahkan masalah.
Sebagian besar mahasiswa kelompok tinggi belum mempunyai kebiasaan untuk mencoba menyelesaikan sebuah persoalan dengan alternatif solusi lain yang bernilai benar. Perilaku ini mengakibatkan mereka tidak bisa mengetahui tentang kapan seharusnya menggunakan suatu prosedur, keterampilan, atau strategi dan bilamana hal-hal tersebut tidak digunakan, mengapa suatu prosedur bisa berlangsung dan dalam kondisi yang bagaimana berlangsungnya, dan mengapa suatu prosedur lebih baik daripada prosedur yang lain. Pengetahuan yang demikian disebut dengan pengetahuan kondisional (Peirce, 2003: 2). Dengan kata lain bahwa sebagian besar mahasiswa kelompok tinggi belum memiliki pengetahuan kondisional dalam memecahkan masalah.

Mahasiswa yang tidak memiliki pengetahuan kondisional tidak dapat memutuskan prosedur penyelesaian mana yang paling efektif digunakan untuk menyelesaikan persoalan. Selain itu mahasiswa tidak dapat mengetahui karakteristik persoalan yang dapat diselesaikan dengan sebuah prosedur. Hal ini berimplikasi pada kurangnya keterampilan mahasiswa dalam berfikir kreatif, mengambil keputusan dan memprediksi.

\section{Mahasiswa Kelompok Sedang}

Berdasarkan hasil wawancara dengan seluruh mahasiswa kelompok sedang ditemukan bahwa semua mahasiswa kelompok sedang belum mencoba menemukan alternatif solusi lain yang bernilai benar dari sebuah persoalan. Sewaktu wawancara, pada umumnya mahasiswa kelompok sedang mengungkapkan bahwa mereka tidak mau mencoba memecahkan masalah dengan berbagai alternatif solusi yang bernilai benar karena mereka merasa cukup puas bisa menyelesaikan dengan satu prosedur saja.

Berdasarkan hasil wawancara tersebut, dapat disimpulkan bahwa semua 
mahasiswa kelompok sedang belum mempunyai kebiasaan untuk mencoba menyelesaikan sebuah persoalan dengan alternatif solusi lain yang bernilai benar. Perilaku ini mengakibatkan mereka tidak bisa mengetahui tentang kapan seharusnya menggunakan suatu prosedur, keterampilan, atau strategi dan jika hal-hal tersebut tidak digunakan, mengapa suatu prosedur bisa berlangsung dan dalam kondisi yang bagaimana berlangsungnya, dan mengapa suatu prosedur lebih baik daripada prosedur yang lain. Dengan demikian bahwa mereka belum memiliki pengetahuan kondisional dalam memecahkan masalah (Peirce, 2003: 2).

Mahasiswa yang tidak memiliki pengetahuan kondisional tidak dapat memutuskan prosedur penyelesaian mana yang paling efektif digunakan untuk menyelesaikan persoalan. Selain itu mereka tidak dapat mengetahui karakteristik persoalan yang dapat diselesaikan dengan suatu prosedur tertentu. Hal ini berimplikasi pada kurangnya keterampilan mereka dalam berfikir kreatif, mengambil keputusan dan memprediksi.

\section{Mahasiswa Kelompok Rendah}

Pada saat wawancara diperoleh informasi bahwa mahasiswa kelompok rendah tidak mencoba dan tidak mampu menemukan alternatif solusi lain yang bernilai benar dari sebuah persoalan. Mereka mengungkapkan bahwa mereka tidak melakukan hal tersebut dikarenakan sulit dalam menemukan sebuah ide penyelesaian masalah. Ini berkaitan dengan aspek keyakinan diri dan intuisi yang dimiliki oleh mahasiswa kelompok rendah yang kurang seperti yang sudah dijelaskan sebelumnya. Selain itu, hal ini juga disebabkan oleh gaya belajar matematika mahasiswa kelompok rendah yang cenderung menghafal rumus dan penyelesaian masalah yang sudah dibahas/dikerjakan, tanpa mengetahui hakikat dari rumus tersebut. Gaya belajar seperti ini beresiko, karena hanya mengandalkan short time memories.

Ketidakmampuan mahasiswa kelompok rendah ini membuat ia tidak mengetahui bagaimana dan bilamana suatu prosedur efektif digunakan dan untuk jenis persoalan yang mana prosedur tersebut bisa digunakan. Kesimpulannya mahasiswa kelompok rendah belum memiliki pengetahuan kondisional dalam memecahkan masalah.

\section{PENUTUP}

Penelitian ini telah memberikan gambaran keyakinan diri dan intuisi serta pengetahuan tentang proses berfikir mahasiswa (kelompok tinggi, sedang, dan rendah) dalam memecahkan masalah matematika. Dari penelusuran ini, dapat disimpulkan bahwa keyakinan diri dan intuisi yang dimiliki oleh mahasiswa kelompok tinggi dan sedang disebabkan karena mereka memiliki pemahaman konsep yang baik terhadap konsep yang mendasari penyelesaian masalah, khususnya konsep "Kombinatorik dan Peluang". Ketidakmampuan mahasiswa kelompok rendah dalam menemukan ide penyelesaian masalah disebabkan karena mereka tidak memiliki intuisi dan keyakinan diri yang baik dalam memulai memecahkan masalah. Jadi, keyakinan diri dan intuisi dapat dikembangkan dalam diri seseorang melalui berfikir aktif dalam memahami dan mengelaborasi konsep/materi pelajaran.

Pengetahuan tentang proses berfikir mahasiswa sangat berpengaruh terhadap pencapaian perolehan belajarnya. Mahasiswa yang mendapatkan perolehan belajar kategori tinggi memiliki pengetahuan tentang proses berfikir yang baik mulai dari memahami masalah sampai menemukan solusi dari permasalahan yang diberikan. Salah satu penyebab sebagian mahasiswa mendapatkan perolehan belajar sedang adalah tidak memiliki pengetahuan tentang proses ber- 
fikir yang baik dalam menjalankan strategi penyelesaian masalah. Padahal mereka memiliki keyakinan diri dan intuisi yang cukup, namun mereka tidak mampu mengelola ide dan konsep dengan baik sehingga penyelesaian masalah yang dibuat tidak sistematis. Kesimpulan lain yang berkenaan dengan perilaku metakognitif kedua ini adalah sebagian besar mahasiswa tidak memiliki pengetahuan kondisional, sehingga dapat dikatakan bahwa mahasiswa belum mampu berfikir kritis dan kreatif dalam memecahkan masalah.

Hasil penelitian ini merupakan gambaran karakteristik perilaku intelektual mahasiswa dalam memecahkan ma-

\section{DAFTAR RUJUKAN}

Abdul Muin, 2006. Pendekatan Metakognitif untuk Meningkatkan $\mathrm{Ke}$ mampuan Matematika Siswa SMA (Algoritma, vol.2). Jakarta: Jurusan Pendidikan Matematika UIN Syarif Hidayatullah.

Biryukov, P. 2004. Metacognitive Aspects of Solving Combinatorics Problems. Dalam International Journal for Mathematics Teaching and Learning (Online), Vol 1 (74) ISSN 1473 - 0121, Tersedia: http://www.ex.ac.uk/cimt/ijmt/biry ukov.pdf (2 Juni 2009).

Blakey, E \& Spence, S, 1990. Developing Metacognitive. dalam Eric Degests on Information Resources (Online).

Tersedia: http://www.iap.ac.id/ERICDigests/ metacognitive.html (17 Juli 2009)

Fajar Shadiq, 2004. Pemecahan Masalah, Penalaran dan Komunikasi. Jakarta: Depdiknas.

Huitt, B, 1997. Educational Psycholo-gy Interactive: Metacognition (Online). Tersedia: http://chiron. Valdosta.edu/whuitt/Col/Cogsys/Meta cogn.html (17 Juli 2009).

Meyer, M.C, 2002. To Foster Development of Cognitive Strategies, salah. Temuan ini dapat dijadikan pedoman bagi dosen untuk memperbaiki proses pembelajaran sehingga mahasiswa memiliki perilaku metakognitif dalam belajar yang berujung pada terbentuknya mahasiswa yang memiliki karakter mandiri, kritis, dan kreatif. Di samping itu, penelitian ini juga menghasilkan pedoman penelusuran perilaku metakognitif di setiap langkah pemecahan masalah yang diungkapkan oleh Polya melalui observasi dan wawancara. Pedoman ini dapat digunakan oleh peneliti dan dosen untuk mengenali perilaku metakognitif mahasiswa dalam mencapai tujuan belajar.

Use Embedded Scaffolding Techniques. (Online). Tersedia: http://coe.sdsu.edu/EDTEC640/PO Psamples/mmeyer/mmeyer.htm (21 juli 2009).

Usman, Mulbar, 2008. Metakognisi Siswa dalam Menyelesaikan Masalah Matematika. (Online). Tersedia: http://www. Usmanmulbar. files. wordpress.com.

Schoenfeld, A, 1985. Mathematical Problem Solving. (Online). Tersedia: http://tip.psychology.org/ schoen.html [21 April 2009]

1987. Metacognition. Learning and Mathematics (Online). Tersedia:

http://mathforum.org/ sarah/Discu ssion.Sessions/schoenfeld.html (21 April 2009)

, 1992. Learning To Think Mathematically: Problem Solving, Metacognition, And Sense Making in Mathemaics. Handbook for Reseacrch on Mathematics Teaching and Learning. New York: MacMillan. [Online]. Tersedia: http://myschoolnet.ppk.kpm.my/bc b8.pdf. 
